\title{
Черезшкірна нефростомія як перший етап малоінвазивного лікування ретенційних захворювань верхніх сечовиді.льних ш.ляхів
}

\author{
R. R. ZAHORUYKO \\ Lviv National Medical University by Danylo Halytskyi
}

\section{PERCUTANEOUS NEPHROSTOMY AS A FIRST STAGE OF THE MINIMALLY INVASIVE TREATMENT WITH OBSTRUCTION OF PATHOLOGIES OF THE UPPER URINARY TRACT}

\begin{abstract}
Дослідили історії хвороб 97 хворих, які перебували в урологічному відділі ЛОКЛ у 2009-2013 рр. Перший етап малоінвазивного лікування ретенційних процесів верхніх сечовидільних шляхів (ВСВШ) на Ірунті сечокам'яної хвороби (CKX) - конкрементів нирки, сечовода, стриктури сечовода, викликаної тривалим перебуванням конкремента, гідронефрозу на црунті вади пієлоуретерального сегмента (ПУС) та термінального гідро-, піонефрозу, після невдалого дренування ВСВШ стентом ЈЈ полягає у встановленні під УЗ-контролем черезшкірної нефростоми. Після нормалізації клініко-лабораторних показників через 4-6 тижнів після I етапу виконується II етап малоінвазивного лікування патології ВСВШ - URS, ЧШНЛ (черезшкірна нефролітотрипсія, лапаксія), лазерна літотрипсія.
\end{abstract}

\begin{abstract}
We analyzed the treatment of 97 patients treated in urological department in 2009-2013.The first stage of the minimally invasive treatment of the obstruction of the upper urinary tract caused by the urolithiasis - kidney calculus, ureter, ureteral stricture caused by the long-term stone impaction, hydronephrosis caused by the pyelourethral segment (PUS) and the terminal hydro(pyo)nephrosis) after the $\mathrm{JJ}$ stenting failure includes the percutaneous nephrostomy under the ultrasound control. In 4-6 weeks after the normalization of laboratory and clinical parameters we perform the second stage of the definitive treatment: URS, PNL, laser lithotripsy.
\end{abstract}

Постановка проблеми і аналіз останніх досліджень та публікацій. Широке впровадження в клінічну практику ендоскопічного малоінвазивного лікування патології ВСВШ змінило тактику лікування CKX, уроджених вад нирки (гідронефрозу на грунті вадипієлоуретерального сегмента), піонефрозу, стриктури сечовода на грунті CKX, ускладненої хронічним ретенційним пієлонефритом. Сучасні підходи в лікуванні наведених патологічних процесів полягають у переведенні ургентного стану, викликаного порушенням уродинаміки із розвитком ретенційного гнійного пієлонефриту, в стан, при якому може бути виконано операційне лікування в плановому порядку. Дане питання недостатньо висвітлено в літературі. Метою дослідження було вивчення можливості дренування ВСВШ під УЗ-контролем при патології ВСВШ.

Для досягнення мети було сформульовано такі завдання:

1. Вивчити клініко-лабораторні показники у хворих з СKX, уродженими аномаліями нирок до черезшкірного дренування під УЗ-контролем як перший етап малоінвазивного лікування патології ВСВШ.

2. Встановити весь спектр нозології та типи малоінвазивних втручань у хворихпісля черезшкірної нефростомії як другий етап лікування патології ВСВШ.

Матеріали і методи. Дослідили історії хвороб 97 хворих з СКХ, ускладненими ретенційними пієлонефритами без деструктивних змін ВСВШ, які перебували в урологічному відділі ЛОКЛ в 20092013рр. Із 97 хворих було 52 жінки та 45 чоловіків, вік хворих чоловіків становив $(56 \pm 1,2)$ та жінок $(59 \pm 2,0)$ року. Із 97 хворих у 40 процес був лівобічний, у 45 правобічний та у 12 хворих - двобічний. У таблиці 1 представлено нозології хвороб ВСВШ, при яких було виконано під УЗ-контролем черезшкірну нефростомію.

Як бачимо із представлених у таблиці 1 даних, найбільше хворих, яким виконували I етап лікування ретенційних запальних процесів ВСВШ під УЗ-контролем шляхом встановлення черезшкірної нефростоми, це хворі з конкрементами сечоводів - 36 із 97, на другому місці за частотою - це хворі із стриктурами сечоводів на грунті СКХ, ускладненої ретенційним пієлонефритом - 22 із 97 хворих, значно рідше дренували ВСВШ при загостренні хронічного пієлонефриту при коралоподібних конкрементах нирок у 15 із 97 та 
Таблиця 1. Черезшкірна нефростомія - перший етап лікування патології ВСВш, ускладненої обструктивним ретенційним пієлонефритом

\begin{tabular}{||l|c||}
\hline \multicolumn{1}{|c|}{ Нозологія } & Кількість хворих \\
\hline СКХ. Коралоподібний конкремент нирки & 15 \\
\hline Конкременти сечовода, ретенційний пієлонефрит & 36 \\
\hline Вада ПУС, загострення хронічного пієлонефриту & 14 \\
\hline Стриктура сечовода на грунті СКХ, хронічний ретенційний пієлонефрит & 22 \\
\hline Термінальний гідро-, піонефроз & 10 \\
\hline Всього & 97 \\
\hline
\end{tabular}

при гідронефрозах на грунті вади ПУС, ускладненої хронічним пієлонефритом у 14 із 97. На останньому місці за частотою були хворі з термінальними гідро- та піонефрозами - 10 із 97 хворих.

Всім їм проводили загальноклінічні аналізи крові, сечі, біохімічні показники крові (сечовина, креатинін, електроліти, печінкові проби) (табл. 2); групи крові, резус-фактора; рентгенологічні - оглядова та екскреторна урографія, при потребі - КТ з контрастуванням. Використовували Rtg-дугу Siemens, уретерореноскоп Storz 9,8 Fr, лазерний літотриптор Calculaser, нефроскоп Storz 26 Fr.

Таблиця 2. Деякі клінічні та лабораторні показники обстеження хворих із запальними процесами ВСВш до встановлення черезшкірної нефростомії

\begin{tabular}{|c|c|c|c|c|c|}
\hline Нозологія & $\begin{array}{c}\text { Температурна реакція } \\
\text { при госпіталізації }\end{array}$ & Нb крові & $\begin{array}{l}\text { Лейкоцитоз } \\
\text { крові }\end{array}$ & $\begin{array}{l}\text { Зсув у формулі } \\
\text { паличкоядерних }\end{array}$ & ШOE \\
\hline $\begin{array}{l}\text { Конкремент нирки, хронічний } \\
\text { калькульозний пієлонефрит, } \\
\text { n=15 }\end{array}$ & $37,8 \pm 1,89$ & $110 \pm 5,52$ & $11,5 \pm 0,57$ & $10 \pm 0,51$ & $42 \pm 2,15$ \\
\hline $\begin{array}{l}\text { Конкремент сечовода, } \\
\text { ретенційний пієлонефрит, } \\
\text { n=36 }\end{array}$ & $38,3 \pm 1,91$ & $98 \pm 4,91$ & $15,4 \pm 0,77$ & $20,2 \pm 1,01$ & $48 \pm 2,43$ \\
\hline $\begin{array}{l}\text { Вада ПУС, загострення } \\
\text { хронічного пієлонефриту, } \\
\text { n=14 }\end{array}$ & $37,4 \pm 1,87$ & $105 \pm 5,25$ & $9,1 \pm 0,45$ & $124 \pm 0,64$ & $37 \pm 1,85$ \\
\hline $\begin{array}{l}\text { Стриктура сечовода на грунті } \\
\text { СКХ, хронічний ретенційний } \\
\text { пієлонефрит, n=22 }\end{array}$ & $38,4 \pm 1,92$ & $97 \pm 4,85$ & $16,1 \pm 0,85$ & $18 \pm 0,92$ & $52 \pm 2,64$ \\
\hline $\begin{array}{l}\text { Термінальний гідро-, } \\
\text { піонефроз, n=10 }\end{array}$ & $38,5 \pm 1,93$ & $92 \pm 4,63$ & $18,3 \pm 0,92$ & $24 \pm 1,22$ & $56 \pm 2,82$ \\
\hline $\mathrm{t} 1,2$ & 2,48 & 2,31 & 1,86 & 2,58 & 2,17 \\
\hline $\mathrm{p} 1,2$ & 0,02 & 0,02 & 0,05 & 0,02 & 0,05 \\
\hline$t 1,3$ & 2,76 & 1,87 & 2,84 & 2,65 & 2,07 \\
\hline $\mathrm{p} 1,3$ & 0,01 & 0,05 & 0,01 & 0,05 & 0,02 \\
\hline $\mathrm{t} 1,4$ & 2,03 & 2,55 & 2,38 & 2,69 & 2,11 \\
\hline $\mathrm{p} 1,4$ & 0,05 & 0,02 & 0,05 & 0,01 & 0,02 \\
\hline $\mathrm{t} 1,5$ & 2,79 & 2,43 & 2,69 & 2,54 & 1,94 \\
\hline $\mathrm{p} 1,5$ & 0,01 & 0,05 & 0,02 & 0,01 & 0,05 \\
\hline $\mathrm{t} 2,3$ & 2,35 & 2,71 & 2,47 & 3,84 & 2,09 \\
\hline p 2,3 & 0,05 & 0,2 & 0,05 & 0,02 & 0,01 \\
\hline t 2,4 & 2,27 & 2,48 & 2,15 & 2,47 & 2,58 \\
\hline p 2,4 & 0,05 & 0,01 & 0,05 & 0,02 & 0,01 \\
\hline t 2,5 & 2,55 & 2,09 & 2,61 & 2,59 & 2,04 \\
\hline $\mathrm{p} 2,5$ & 0,02 & 0,05 & 0,02 & 0,02 & 0,05 \\
\hline t 3,4 & 2,68 & 2,03 & 2,71 & 2,95 & 2,04 \\
\hline p 3,4 & 0,02 & 0,05 & 0,01 & 0,01 & 0,05 \\
\hline $\mathrm{t} 4,5$ & 2,56 & 2,41 & 2,71 & 2,19 & 3,05 \\
\hline p 4,5 & 0,02 & 0,05 & 0,02 & 0,05 & 0,01 \\
\hline
\end{tabular}

Результати досліджень та їх обговорення. Якщо оцінити температурну реакцію в момент госпіталізації, то найбільш вираженою вона бу- ла у хворих із термінальним гідро- та піонефрозом (38,5 $\pm 1,93)$, дещо меншу температурну реакцію спостерігали у хворих із стриктурою сечовода на 
грунті CKX $(38,4 \pm 1,92)$ та при конкрементах сечовода

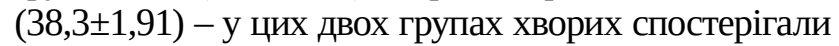
ретенційний гнійний пієлонефрит, спроба дренування ВСВШ за допомогою стента була неуспішною, тому в день госпіталізації всім дренували ВСВШ шляхом встановлення черезшкірної нефростомії. Меншу температурну реакцію спостерігали при конкрементах нирки $(37,8 \pm 1,89)$ та при гідронефрозах на грунті вади розвитку ПУС $(37,4 \pm 1,87)$. Розглянемо ще один важливий показник із загальноклінічних аналізів це гемоглобін крові. Як представлено в таблиці, при гнійних процесах ВСВШ спостерігається зниження гемоглобіну крові до $(92 \pm 4,63)$ при піонефрозі, при конкрементах сечовода та при наявності стриктури сечовода на грунті уретеролітіазу з розвитком ретенційного пієлонефриту до $(97,4 \pm 4,85)$ г/л та $(98,2 \pm 4,91)$ г/л, при відсутності вогнища деструкції показники гемоглобіну вищі, ніж при гнійних процесах, при конкрементах нирки - $(110 \pm 5,52)$ г/л та гідронефрозі на грунті вади ПУС - $(105,4 \pm 5,25)$ г/л, в цих випадках не спостерігали ознак гнійних процесів ВСВШ.

Наступним важливим показником загальноклінічних аналізів є лейкоцитоз. Ми спостерігали хворих віком понад 60 р., особливо тих, у яких був цукровий діабет I або II типів, з нормальними показниками лейкоцитозу $6,7 \times 10^{9} / л \pm 0,33$, додаткові обстежання (КТ із контрастуванням) виявляли наявність ретенційних процесів ВСВШ. Але все ж таки, як представлено в таблиці 2, найвищі показники лейкоцитозу спостерігали при ретенційних процесах

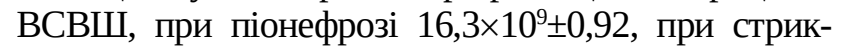
турах сечовода внаслідок тривалого перебування конкремента, ускладнених гнійним ретенційним пієлонефритом $-16,1 \times 10^{9} \pm 0,85$ та при конкрементах сечовода, ускладнених гострим гнійним пієлонефритом - 15,4×10900,77. При загостренні хронічного пієлонефриту без деструкції ВСВШ лейкоцитоз був меншим - при конкрементах нирки - 11,5×109/Л $\pm 0,51$ та при гідронефрозах на грунті вади ПУС $-9,1 \times 10^{9} \pm 0,45$.

Ще одним показником загальноклінічного обстеження крові був зсув уліво у формулі крові до паличкоядерних лейкоцитів. Як бачимо із представлених даних, найбільш виражений зсув уліво до па- личкоядерних лейкоцитів спостерігався у хворих 3 піонефрозом $(24 \pm 1,22)$, але враховуючи невелику вибірку - 10 пацієнтів, ці дані є недостовірними, виражений зсув уліво спостерігали при гнійних ретенційних пієлонефритах у хворих із конкрементами сечоводів $(20,2 \pm 1,01)$ та при наявності стриктури сечовода внаслідок тривалого перебування конкремента (до $(18 \pm 0,92)$ паличкоядерних лейкоцитів). Менший зсув уліво спостерігали при конкрементах нирки та гідронефрозах на грунті вади ПУС, відповідно, до 10 та 12 паличкоядерних лейкоцитів, у цих групах пацієнтів не спостерігали гнійного ретенційного пієлонефриту.

Показник ШОЕ теж мав тенденцію до вираженого підвищення при деструктивних процесах ВСВШ, при піонефрозі до 56 мм/год 2,82 та при стриктурах сечовода на грунті тривалого перебування конкремента до $(52 \pm 2,64)$ мм/год, менш виражене збільшення ШОЕ при загостренні хронічного пієлонефриту, без деструктивних змін ВСВШ при гідронефрозах на грунті вади ПУС - $(37 \pm 1,95)$ мм/год та при конкрементах нирок $(42 \pm 2,25)$ мм/год. Після закінчення першого етапу малоінвазивного лікування такої патології ВСВШ, як конкременти сечовода в 36 пацієнтів із 97 хворих та стриктури сечовода на грунті тривалого перебування конкремента в 22 із 97 хворих, конкрементів нирок у 15 із 97 пацієнтів, гідронефрозу нирок на грунті вади ПУС у 14 хворих та ще в $10-$ термінального гідро-, піонефрозу, цей етап полягав у черезшкірному під УЗ-контролем дренуванні ВСВШ найчастіше через нижню чашку, з метою ліквідації ретенційного або гнійного пієлонефриту провели II етап лікування. Дренування ВСВШ починалося із встановлення стента в усіх наведених випадках, через неможливість встановлення стента в порожнисту систему нирки переходили до встановлення нефростоми під УЗ-контролем. Після нормалізації клініко-лабораторних показників цей період тривав до 4-6 тижнів, виконували малоінвазивне лікування патології ВСВШ, дані наведено в таблиці 3.

Як представлено в таблиці 3, при конкрементах сечовода в 22 хворих виконали УРС з уретеролітотрипсією, в 14 при виконанні УРС відмітили переміщення конкрементів у порожнисту систему

Таблиця 3. Види операційних втручань після черезшкірної нефростомії

\begin{tabular}{||l|c|c|c|c||}
\hline \multicolumn{1}{|c|}{ Нозологія } & $\begin{array}{c}\text { ЧШНЛ, } \\
\text { ендопієлотомія }\end{array}$ & $\begin{array}{c}\text { URS, лазерна } \\
\text { уретеролітотрипсія }\end{array}$ & Нефректомія & URS+ЧШНЛ \\
\hline Конкременти нирки & 15 & & 12 & 14 \\
\hline $\begin{array}{l}\text { Конкременти сечовода, хронічний } \\
\text { ретенційний пієлонефрит }\end{array}$ & & 14 & 16 & \\
\hline Вади розвитку нирки & 14 & & & \\
\hline Стриктура сечовода на грунті СКХ & & 10 & 10 & 6 \\
\hline Термінальний гідро-, піонефроз & 10 & & & \\
\hline
\end{tabular}


нирки, тому додатково виконали нефролітотрипсію (лапаксію), в 15 хворих із конкрементами нирок виконано черезшкірну нефролітотрипсію, в 16 хворих із стриктурами сечоводів внаслідок тривалого перебування конкрементів виконано URS із уретеролітотрипсією, в 6 поряд 3 URS виконано черезшкірну нефролітотрипсію (лапаксію), у 14 хворих із гідронефрозом на грунті вади ПУС виконано ендопієлотомію, та в 10 хворих із термінальними гідро-, піонефрозами - нефректоміі.

Висновки. 1. Перший етап малоінвазивного лікування ретенційних процесів ВСВШ на грунті СКХ конкрементів нирки, сечовода, стриктури сечовода, викликаної тривалим перебуванням конкремента, гідронефрозу на грунті вади ПУС та термінального гідро-, піонефрозу після невдалого дренування ВСВШ стентом јј полягає у встановленні під УЗконтролем черезшкірної нефростоми.

2. При клініко-лабораторному обстеженні хворих із ретенційними процесами ВСВШ температурна реак-

\section{СПИСОК ЛІТЕРАТУРИ}

1. Возианов А. Ф. Атлас-руководство по урологии / А. Ф. Возианов, А. В. Люлько. - РИА “Дніпро-VAL”, 2001. - T.2. 674 c.

2. Андон'єва Н. М. Урологія. Діючі протоколи надання медичної допомоги / Н. М. Андон'єва, О. В. Борисов, О. Ф. Возіанов. - К. : Здоров'я України, 2011. - С. 222-232, 464-473.

3. Антонян М. И. Роль уретерореноскопии и пункционной нефростомии в диагностике и лечении верхних мочевых путей / М. И. Антонян, А. В. Стецишин, А. В. Чепенко // Урология. - 2010. - № 14. - С. 243.

4. Борисов С. О. Застосування сучасних малоінвазивних методик дренування верхніх сечових шляхів при обструктивній ція більш виражена при гнійних обструктивних процесах ВСВШ - ретенційному гнійному пієлонефриті на грунті стриктури сечовода внаслідок тривалого перебування конкремента в сечоводі та при піонефрозі, відповідно, $(38,4 \pm 38,5){ }^{0} \mathrm{C}$ при загостренні хронічного пієлонефриту, не ускладненого гнійним процесом, температурна реакція менш виражена - 37,8 ㄷ․

3. Ряд інших показників, таких як гемоглобін крові, лейкоцитоз, зсув формули крові до паличкоядерних лейкоцитів, ШОЕ теж мають свої особливості при гнійних деструктивних формах хронічного пієлонефриту, - спостерігається, зокрема, зниження гемоглобіну із більш вираженим лейкоцитозом і зсувом до паличкоядерних лейкоцитів та вираженим прискоренням ШОЕ, ніж при неускладнених деструктивних процесах, хронічних пієлонефритах.

4. Після нормалізації клініко-лабораторних показників через 4-6 тижнів після I етапу виконується II етап малоінвазивного лікування патології ВСВШ - URS, ЧШНЛ (черезшкірна нефролітотрипсія, лапаксія).

нефропатії / С. О. Борисов, Ф. І. Костєв, О. В. Борисов // Шпитальна хірургія. - 2006. - № 4. - С. 23-25.

5. Возіанов С. О. Черезшкірна пункційна нефростомія при обструкції верхніх сечових шляхів / С. О. Возіанов, О. В. Гогуленко // Урологія. - 2004. - № 1. - С. 22-24.

6. Lewis S. Major complications after percutaneous nephrostomy-lessons from a department audit / S. Lewis, S. Major, U. Patel // Clin. Radiol. - 2004. - Vol. 52, № 1. - P. 171-179.

7. Ureteral stent symptom questionnaire: development and validation of multidimensional quality of life measure / H. Joshi, N. Newns, A. Stainhorpe [et al.] // J. Urol. (Baltimore). - 2003. - Vol. 169. - P. 1060-1064. 